\title{
Management of bacterial leaf blight of mango through antibiotics and bio-fungicide
}

\begin{abstract}
An experiment was conducted in the net house, Department of Plant Pathology, Bangladesh Agricultural University, Mymensingh, Bangladesh during 15 July 2012 to June 2013 to find out the efficacy of antibiotics and biofungicide for controlling bacterial leaf blight of mango. Six treatments were applied viz., (i) T1ї Gentamycin@ $0.05 \%$, (ii) T2ï Erithromycin@ $0.05 \%$, (iii) T3ï Doxycycline@0.05\%, (iv) T4ї Copper sulphate @ 0.05\%, (v) T5Ï BAUbiofungicide@2\% and (vi) T6ï Control. The treatment BAU-biofungicide was found good in controlling bacterial leaf blight of mango. This treatment increased $23.71 \%$ plant height, $53.33 \%$ branch over control and reduced $39.31 \%$ disease incidence and $48.50 \%$ disease severity when applied as foliar spray @ 2\%. The second best control measure was found by gentamycin as it reduced $28.46 \%$ disease incidence and $46.43 \%$ disease severity when applied as foliar spray @ $0.05 \%$, although other treatments reduced incidence and severity of bacterial leaf blight which were applied as foliar spray @ $0.05 \%$.
\end{abstract}

Keyword: Antibiotics; Bacterial leaf blight; Management; Mango 